\title{
Nanocristais de celulose bacteriana: da obtenção, sob diferentes condições de hidrólise, à incorporação como reforço em poli(L-ácido láctico)
}

\author{
Bacterial cellulose nanocrystals: from obtaining, \\ under different hydrolysis conditions, the \\ incorporation as reinforcement \\ in poly(L-lactic acid)
}

Juliana Francine da Costa ${ }^{1}$, Michele Cristina Formolo Garcia ${ }^{1}$, Giannini Pasisnick Apati ${ }^{1}$, Hernane da Silva Barud ${ }^{2}$ Andrea Lima dos Santos Schneider ${ }^{1}$, Ana Paula Testa Pezzin ${ }^{1}$

\footnotetext{
${ }^{1}$ Mestrado em Engenharia de Processos (MEP) - UNIVILLE - CEP: 89219-710, Joinville, SC

e-mails: juliana.francine.costa@posgrad.ufsc.br; michelegarcia@univille.br; giannini.apati@univille.br; aschneider@univille.br; anapezzin@yahoo.com.br

${ }^{2}$ Laboratório de Biopolímeros e Biomateriais (BioPolMat) - UNIARA - CEP: 14801-340, Araraquara, SP e-mail: hernane.barud@gmail.com
}

\begin{abstract}
RESUMO
Este trabalho almejou produzir celulose bacteriana (CB), obter nanocristais de celulose bacteriana (NCCB), incorporar NCCB como reforço em poli(L-ácido láctico) (PLLA) e avaliar propriedades destes bionanocompósitos. Foram produzidas membranas de CB provenientes da bactéria Gluconacetobacter hansenii. A partir das membranas foram obtidos NCCB por hidrólise com ácido sulfúrico $\left(\mathrm{H}_{2} \mathrm{SO}_{4}\right)$, com base em 11 experimentos. Os parâmetros variados nos experimentos foram: concentração de $\mathrm{H}_{2} \mathrm{SO}_{4}$, temperatura e tempo. Pode-se definir critérios de obtenção de NCCB por análise termogravimétrica (TGA) e análise de espalhamento dinâmico de luz (DLS). Principais resultados indicam possibilidade de obtenção na condição de: $80 \%$ de concentração de $\mathrm{H}_{2} \mathrm{SO}_{4}(\mathrm{~m} / \mathrm{m}), 60^{\circ} \mathrm{C}$ e $60 \mathrm{~min}$. Para esta condição obteve-se tamanhos adequados dos NCCB (média de $388 \mathrm{~nm})$, potencial zeta adequado $(-38 \mathrm{mV})$ e estabilidade térmica adequada $\left(\mathrm{T}_{\text {onset2 }}=\right.$ $\left.301,9{ }^{\circ} \mathrm{C}\right)$. Posteriormente, NCCB obtidos conforme critérios definidos foram incorporados ao PLLA em duas concentrações (2,5 e 5\%), utilizando dois métodos (sem e com funcionalização dos NCCB). Os bionanocompósitos preparados foram caracterizados por TGA e calorimetria explanatória diferencial (DSC). Resultados das técnicas de caracterização dos bionanocompósitos foram comparados com resultados do PLLA puro. Principais resultados em relação aos métodos, revelam a importância da funcionalização dos NCCB antes de incorporá-los ao PLLA. Sobre a concentração de reforço utilizada, o aumento da estabilidade térmica foi gradual, conforme teor de reforço, sendo que para o bionanocompósito com 5\% de NCCB funcionalizados o incremento foi de $10,4{ }^{\circ} \mathrm{C}$ na $\mathrm{T}_{\text {onset2 }}$ em relação ao PLLA puro. Contudo, o grau de cristalinidade diminuiu $\left(\mathrm{X}_{\mathrm{c}}\right.$ do PLLA puro $=40,38 \%$ e $\mathrm{X}_{\mathrm{c}}$ do bionanocompósito com 5\% de NCCB funcionalizados $=24,73 \%)$. Conclui-se que a adição de NCCB em PLLA é ambientalmente viável e promove melhoria de propriedades.
\end{abstract}

Palavras-chave: bionanocompósitos, nanocristais de celulose bacteriana, poli(L-ácido láctico).

\section{ABSTRACT}

This work aimed to produce bacterial cellulose, to obtain bacterial cellulose nanocrystals, to incorporate nanocrystals as a reinforcement in poly(L-lactic acid) and to evaluate the properties of these bionanocomposites. Bacterial cellulose membranes from the bacterium Gluconacetobacter hansenii were produced. From the membranes were obtained nanocrystals by hydrolysis with sulfuric acid $\left(\mathrm{H}_{2} \mathrm{SO}_{4}\right)$, based on 11 experiments. The parameters varied in the experiments were: concentration of $\mathrm{H}_{2} \mathrm{SO}_{4}$, temperature and 
time. It is possible to define criteria for obtaining nanocrystals by thermogravimetric analysis and analysis of dynamic scattering of light. Main results indicate the possibility of obtaining in the condition of: $80 \%$ concentration of $\mathrm{H}_{2} \mathrm{SO}_{4}(\mathrm{~m} / \mathrm{m}), 60{ }^{\circ} \mathrm{C}$ and $60 \mathrm{~min}$. For this condition, suitable sizes of the nanocrystals (mean $388 \mathrm{~nm})$, suitable zeta potential $(-38 \mathrm{mV})$ and adequate thermal stability $\left(\mathrm{T}_{\text {onset } 2}=301.9^{\circ} \mathrm{C}\right)$ were obtained. Subsequently, nanocrystals obtained according to defined criteria were incorporated into poly(L-lactic acid) in two concentrations (2,5 and 5\%), using two methods (without and with functionalization of nanocrystals). The prepared bionanocomposites were characterized by thermogravimetric analysis and differential explanatory calorimetry. Results of the techniques of characterization of bionanocomposites were compared with results of pure poly(L-lactic acid). Main results regarding the methods, reveal the importance of the functionalization of the nanocrystals before incorporating them to the poly(L-lactic acid). On the reinforcement concentration used, the increase of the thermal stability was gradual, according to reinforcement content, and for the bionanocomposite with $5 \%$ functionalized nanocrystals the increase was of $10,4^{\circ} \mathrm{C}$ in the $\mathrm{T}_{\text {onset } 2}$ in relation to the poly(L-lactic acid) pure. However, the degree of crystallinity decreased ( $X_{c}$ of pure PLLA $=40,38 \%$ and $X_{c}$ of bionanocomposite with $5 \%$ of functionalized nanocrystals $=24,73 \%$ ). It is concluded that the addition of bacterial cellulose nanocrystals in poly(L-lactic acid) is environmentally feasible and improves properties.

Keywords: Bionanocomposites, bacterial cellulose nanocrystals, poly(L-lactic acid).

\section{INTRODUÇÃO}

Pesquisas envolvendo polímeros provenientes de fontes renováveis e biodegradáveis vêm ganhando destaque devido à constante busca por materiais sustentáveis que possam substituir total ou parcialmente os polímeros sintéticos, provenientes geralmente da cadeia petroquímica, atualmente produzidos em larga escala [1]. Neste sentido, a celulose $\left(\mathrm{C}_{6} \mathrm{H}_{10} \mathrm{O}_{5}\right)_{n}$ é considerada bastante atraente. É o polímero natural mais abundante na biosfera, sendo a celulose extraída de fonte vegetal a mais explorada comercialmente, devido a sua disponibilidade. Porém, além desta fonte, a celulose pode ser produzida por algas e animais marinhos (como os tunicados) e secretadas extracelularmente por diversas cepas de bactérias, como as do gênero Gluconacetobacter [2, 3, 4, 5].

A celulose bacteriana (CB) possui a mesma fórmula química estrutural da celulose vegetal, porém propriedades mecânicas e físicas diferenciadas. A grande vantagem refere-se à pureza, pois não contém lignina, hemiceluloses e outros constituintes presentes em materiais lignocelulósicos [6,7].

A CB surge como uma alternativa competitiva, possuindo como principais características: alta cristalinidade, alta resistência à tração, elasticidade, durabilidade, potencial hidrofílico (capacidade de retenção e absorção de água - cerca de 98 \% a 99 \% de seu volume é composto de líquidos), atoxicidade, biocompatibilidade e biodegradabilidade. Estas importantes propriedades têm conduzido pesquisadores a encontrar aplicações para este material [3, 5, 6, 7, 8].

A CB também pode ser uma fonte de obtenção de nanocristais, que consistem em domínios cristalinos de fibras celulósicas, isolados por meio de hidrólise ácida ou enzimática, representando as melhores propriedades da CB em relação à força e resistência. Além disto, estes nanocristais de celulose bacteriana (NCCB) podem apresentar alta razão de aspecto (comprimento/diâmetro), o que lhes confere boa capacidade de reforço, podendo ser utilizados em diversas matrizes poliméricas [6,9].

A literatura reporta alguns exemplos de obtenção de NCCB. Porém, estudos envolvendo influência das condições de hidrólise ácida, como tipo e concentração de ácido empregado, temperatura e tempo de hidrólise, devem ser mais explorados para que se encontre a melhor condição de obtenção de nanocristais, com dimensões, cristalinidade e estabilidade térmica favoráveis [9,10].

O poli(L-ácido láctico) (PLLA) é um polímero com propriedades promissoras, que tem como monômero estrutural o ácido láctico, um ácido orgânico de origem biológica, sintetizado via fermentativa a partir de fontes renováveis e abundantes. É biodegradável, reabsorvível, biocompatível, termoplástico e hidrofóbico. Estes atributos permitem que o material tenha uma gama de aplicações nas áreas médica e ambiental. No entanto, algumas características, como sua elevada temperatura de transição vítrea (cerca de $60^{\circ} \mathrm{C}$ ) e alta cristalinidade, que tornam o polímero quebradiço e rígido, limitam algumas de suas aplicações [11]. Sua baixa propriedade de barreira a gases também compromete a utilização do polímero em algumas aplicações, como no uso de determinadas embalagens alimentícias e de refrigerantes. Em se tratando de propriedades mecânicas, os polilactídeos são polímeros relativamente frágeis, apresentando resistência ao impacto em torno de $26 \mathrm{~J} / \mathrm{m}$. Para melhorar as propriedades mecânicas, muitas estratégias têm sido avaliadas, como: diminuição do grau de cristalinidade, modificação das propriedades (por meio do desenvolvimento de copolímeros e blendas) e adição de reforços como os nanocristais de celulose [1,11]. 
De todos os nanocompósitos preparados e estudados com NCCB, a matriz de poli(ácido láctico) (PLA), em suas diferentes formas, é a que tem recebido o maior interesse. Uma alternativa para aproveitar as vantagens que o PLLA apresenta e contornar as desvantagens é a aplicação de reforço de NCCB, para a formação de um bionanocompósito, com comportamentos térmico e mecânico adequados [12, 13, 14].

Diante do exposto, este trabalho almejou produzir CB, obter NCCB (definindo critérios para esta obtenção), incorporar reforço de nanocristais em matriz polimérica de PLLA em diferentes concentrações e avaliar propriedades destes bionanocompósitos.

\section{MATERIAIS E MÉTODOS}

A sequência dos procedimentos metodológicos está listada na Figura 1 e detalhada nos tópicos seguintes.

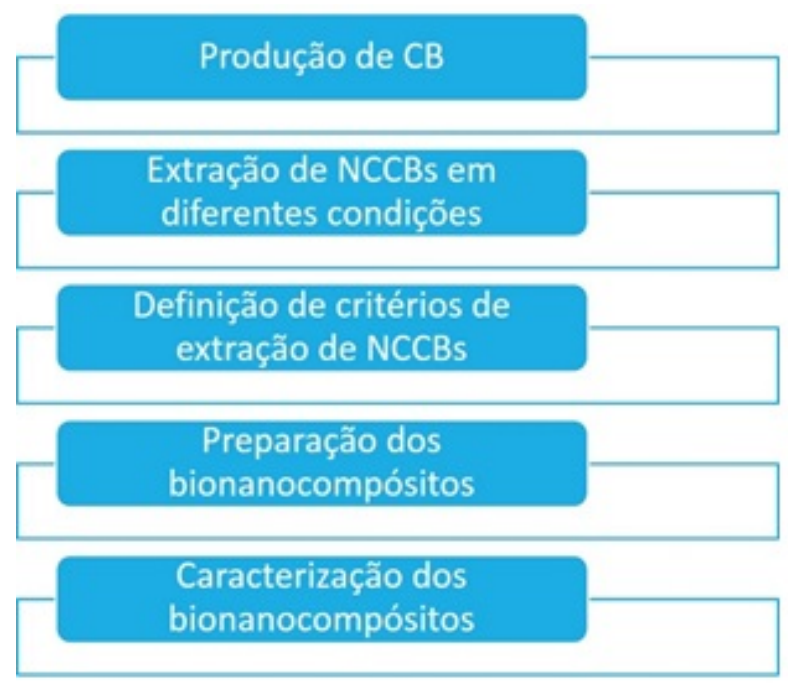

Figura 1: Procedimentos metodológicos.

\subsection{Produção de celulose bacteriana}

Foram sintetizadas 60 membranas de CB. O microrganismo utilizado para a produção de CB foi a bactéria Gluconacetobacter hansenii, da linhagem ATCC 23769. Para a manutenção do microrganismo foi empregado o congelamento em freezer a $-80^{\circ} \mathrm{C}$, tendo glicerol como agente crioprotetor.

O meio de cultivo utilizado tanto na fase de ativação das células (pré-inóculo) quanto na fase de produção das membranas foi o mesmo. Foi constituído de manitol (20 g/L), peptona (5 g/L), extrato de levedura $(5 \mathrm{~g} / \mathrm{L})$, fosfato dissódico $(2,7 \mathrm{~g} / \mathrm{L})$ e ácido cítrico $(1,15 \mathrm{~g} / \mathrm{L})$. O mesmo foi esterilizado em autoclave a $120{ }^{\circ} \mathrm{C}$ por $20 \mathrm{~min}$.

Cada meio de cultivo estéril, contendo $100 \mathrm{~mL}$ de água destilada, foi preparado em frasco de erlenmeyer (com capacidade máxima de $250 \mathrm{~mL}$ ), com $2 \mathrm{~g}$ de manitol (20 g/L), 0,5 g de peptona (5 g/L), 0,5 g de extrato de levedura $(5 \mathrm{~g} / \mathrm{L}), 0,27 \mathrm{~g}$ de fosfato dissódico $(2,7 \mathrm{~g} / \mathrm{L})$ e 0,115 g de ácido cítrico $(1,15 \mathrm{~g} / \mathrm{L})$.

Para a preparação do pré-inóculo, as células foram ativadas em frascos contendo no total $1500 \mathrm{~mL}$ de meio de cultivo, sendo incubadas a temperatura ambiente sob condições estáticas por 2 dias. Após este período, $25 \mathrm{~mL}$ do pré-inóculo (proporção de 20 \% (volume/volume) (V/V)) foram transferidos para cada meio de cultivo, preparados para a produção das membranas e mantidos em cultura estática, sob temperatura ambiente, durante o período de 20 dias, para a produção das mantas hidratadas de CB.

A manta hidratada de CB, produzida na superfície de cada meio de cultivo, foi retirada com o auxílio de pinças. O procedimento seguinte consistiu na purificação destas membranas (mantas hidratadas). Estas foram submetidas a cinco trocas de água destilada por dia, durante três dias. Após as trocas de água, as membranas foram aquecidas em água destilada à temperatura de $80^{\circ} \mathrm{C}$, durante $50 \mathrm{~min}$, em banho-maria. Em seguida, após o descarte da água, para a remoção das bactérias, as membranas foram tratadas com solução de $\mathrm{NaOH}$ 0,1 mol/L, em banho-maria, à temperatura de $80^{\circ} \mathrm{C}$, por $50 \mathrm{~min}$, e então lavadas abundantemente com água destilada até atingir pH 7. Para a secagem foi utilizada estufa com circulação de ar (de marca Memmert), com temperatura de $30^{\circ} \mathrm{C}$, por $36 \mathrm{~h}$. Desta forma, obteve-se finas películas de $\mathrm{CB}$, com aproximadamente 0,3 g. 


\section{2 Obtenção de nanocristais de celulose bacteriana em diferentes condições}

As películas secas de CB produzidas foram trituradas em moinho de facas A 11(de marca IKA).

Os cristais do material polimérico triturado foram obtidos por hidrólise ácida com ácido sulfúrico $\left(\mathrm{H}_{2} \mathrm{SO}_{4}\right)$. O ácido sulfúrico foi escolhido seguindo a literatura, por fornecer suspensões estáveis [10].

Para a definição de critérios de obtenção de NCCB (com a finalidade de empregá-los como reforço em matriz polimérica de PLLA) foram realizados ensaios baseados em um planejamento experimental relacionando onze variações, que podem ser empregadas em hidrólise ácida, utilizando o ácido sulfúrico. Os parâmetros variados foram: concentração de ácido (massa/massa) $(\mathrm{m} / \mathrm{m})$ utilizado na hidrólise, temperatura em que a hidrólise foi realizada e tempo de hidrólise. A Tabela 1 representa as variáveis independentes e os níveis utilizados no planejamento experimental $2^{3}$ completo, com 3 pontos centrais.

Tabela 1. Variáveis independentes e os níveis utilizados no planejamento experimental $2^{3}$ completo, com 3 pontos centrais.

\begin{tabular}{|c|c|c|c|}
\hline \multirow[t]{2}{*}{ PARÂMETROS } & \multicolumn{3}{|c|}{ NÍVEIS } \\
\hline & -1 & 0 & +1 \\
\hline Concentração de ácido (m/m) - [ ] (\%) & 50 & 65 & 80 \\
\hline Temperatura - T $\left({ }^{\circ} \mathrm{C}\right)$ & 40 & 50 & 60 \\
\hline Tempo - t (min) & 20 & 40 & 60 \\
\hline
\end{tabular}

As variáveis médias de concentração de ácido, temperatura e tempo foram definidas com base na literatura, conforme trabalhos de LIMA e colaboradores e TAIPINA [9,10].

A Tabela 2 representa o planejamento experimental completo, com o arranjo das variáveis independentes de cada ensaio.

Tabela 2. Arranjo das variáveis independentes de cada ensaio, conforme planejamento experimental $2^{3}$, completo, com 3 pontos centrais.

\begin{tabular}{l|l|l|l|l|l|l}
\hline \multirow{2}{*}{ ENSAIOS } & \multicolumn{2}{l}{$\begin{array}{l}\text { VARIÁVEIS } \\
\text { CODIFICADAS }\end{array}$} & \multicolumn{2}{l}{$\begin{array}{l}\text { VARIÁVEIS } \\
\text { REAIS }\end{array}$} \\
\hline & {[]$(\%)$} & $\mathrm{T}\left({ }^{\circ} \mathrm{C}\right)$ & $\mathrm{t}(\mathrm{min})$ & {$[\mathrm{l}(\%)$} & $\mathrm{T}\left({ }^{\circ} \mathrm{C}\right)$ & $\mathrm{t}(\mathrm{min})$ \\
\hline 1 & -1 & -1 & -1 & 50 & 40 & 20 \\
\hline 2 & +1 & -1 & -1 & 80 & 40 & 20 \\
\hline 3 & -1 & +1 & -1 & 50 & 60 & 20 \\
\hline 4 & +1 & +1 & -1 & 80 & 60 & 20 \\
\hline 5 & -1 & -1 & +1 & 50 & 40 & 60 \\
\hline 6 & +1 & -1 & +1 & 80 & 40 & 60 \\
\hline 7 & -1 & +1 & +1 & 50 & 60 & 60 \\
\hline 8 & +1 & +1 & +1 & 80 & 60 & 60 \\
\hline 10 & 0 & 0 & 0 & 65 & 50 & 40 \\
\hline 11 & 0 & 0 & 0 & 65 & 50 & 40 \\
\hline & 0 & 0 & 0 & 65 & 50 & 40 \\
\hline
\end{tabular}

Onze amostras, correspondentes aos ensaios foram preparadas em frascos de béqueres identificados, contendo 1,5 g de $\mathrm{CB}$ triturada e $26,25 \mathrm{~mL}$ de solução de $\mathrm{H}_{2} \mathrm{SO}_{4}(\mathrm{~m} / \mathrm{m})$, variando as três diferentes concentrações.

Durante a hidrólise manteve-se agitação constante de $150 \mathrm{rpm}$. Esta condição de agitação e as condições de temperatura foram controladas em shaker (de marca Certomat). Desta forma, os experimentos foram separados de acordo com as temperaturas similares, respeitando os respectivos tempos de reação, que foram cronometrados.

A hidrólise de cada experimento foi cessada diluindo-se a mistura dez vezes com água destilada 
gelada.

As suspensões relativas aos onze ensaios foram centrifugadas três vezes a 8000 rpm, por 10 min, em centrífuga (de marca Labor). Após cada centrifugação, o sobrenadante foi descartado e o precipitado (contendo os NCCB) ressuspenso em água destilada, com o propósito de diminuir a acidez (facilitando a próxima etapa - diálise). A centrifugação foi realizada com refrigeração a $10^{\circ} \mathrm{C}$ para evitar que o processo de hidrólise continuasse, já que é favorecido em altas temperaturas, considerando que o atrito gerado durante a centrifugação aumenta temperatura do equipamento.

O precipitado resultante das onze suspensões (obtido após as centrifugações) foi transferido para membranas de acetato de celulose (de marca Spectra/Por), com diâmetro de $32 \mathrm{~mm}$ e porosidade de 10-12 kD, para diálise contra água destilada até atingir $\mathrm{pH}$ 7. Este procedimento levou de 1-5 dias, dependendo da acidez de cada amostra.

As amostras de NCCB foram sonificadas por 30 min em banho de ultrassom (de marca Thornton). A sonificação é um procedimento que utiliza a energia das ondas sonoras aplicada a um sistema químico, promovendo a agitação das partículas. Esta etapa foi realizada para soltar facilmente as partículas aderidas às paredes dos onze recipientes que continham as amostras e para o rompimento de agregados.

\section{3 Definição de critérios de obtenção de nanocristais de celulose bacteriana}

A definição de critérios de obtenção de NCCB (tendo como base o planejamento experimental) foi feita por meio de análise termogravimétrica (TGA) dos NCCB desidratados, realizada na Universidade de Região de Joinville (UNIVILLE), no Laboratório de Materiais, para o estudo da estabilidade térmica; e análise de espalhamento dinâmico de luz (DLS) dos NCCB em dispersão, na Universidade Estadual Paulista (UNESP), na unidade de Araraquara, no Laboratório de Farmacotécnica, com o objetivo de verificar presença, tamanho e potencial zeta das nanopartículas.

Para a análise termogravimétrica, os NCCB correspondentes aos 11 experimentos, após serem sonificados, foram desidratados por liofilização por $24 \mathrm{~h}$. O equipamento utilizado para a análise foi o TGAQ50, da TA Instruments, sob atmosfera inerte de $\mathrm{N}_{2}$. As amostras foram inseridas no porta-amostras e aquecidas de $25-1000{ }^{\circ} \mathrm{C}$, a uma taxa de aquecimento de $10{ }^{\circ} \mathrm{C} / \mathrm{min}$. Os parâmetros experimentais foram ajustados no software TA Universal Analysis e representados graficamente para interpretação. As curvas de TGA dos NCCB de cada experimento foram comparadas à curva de TGA da CB pura, para melhor compreensão. Uma análise estatística feita utilizando o software Statistica 7 complementou o estudo termogravimétrico.

Para a análise de DLS, as amostras líquidas foram coletadas após o procedimento de sonificação. O equipamento utilizado para a análise foi o Zetasizer Nano Series (de marca Malvern Instruments), em comprimento de onda de $633 \mathrm{~nm}$, a $25^{\circ} \mathrm{C}$, em um ângulo de detecção de $173^{\circ}$. As amostras foram diluídas em água purificada antes de cada medida e as medidas foram feitas em triplicata.

\section{4 Preparação dos bionanocompósitos}

Os NCCB obtidos conforme critérios definidos (melhor condição experimental de hidrólise) foram desidratados por liofilização, durante $24 \mathrm{~h}$.

PLLA (0,75 g) de massa molar de $105.300 \mathrm{~g} / \mathrm{mol}$ (de marca Natural Works) foi dissolvido em clorofórmio $(25 \mathrm{~mL})$, em agitador magnético por $24 \mathrm{~h}$, para formar solução $3 \%(\mathrm{~m} / \mathrm{v})$, conforme metodologia proposta por ALMEIDA [15]. Ao final deste processo, a solução foi vertida em placa de Petri com tampa e mantida em capela de exaustão de gases por $48 \mathrm{~h}$, em temperatura ambiente, para a evaporação lenta do solvente e formação de filme. Após a evaporação do solvente, os filmes foram secos em estufa a vácuo (de marca Nova Ética), a $30^{\circ} \mathrm{C}$, sob pressão de $400 \mathrm{~mm}$ de $\mathrm{Hg}$, por $24 \mathrm{~h}$ e armazenados em dessecador.

Por evaporação de solventes, para a obtenção de filmes reforçados, os NCCB (produzidos conforme a melhor condição experimental de hidrólise) foram incorporados em PLLA de massa molar de $105.300 \mathrm{~g} / \mathrm{mol}$ (de marca Natural Works), em proporções de 2,5 e 5 \%. A incorporação dos NCCB foi realizada por meio de dois métodos, a fim de definir o método que promove melhor dispersão na matriz.

- Método I: utilizando NCCB desidratados

O PLLA $(0,73 \mathrm{~g})$ foi dissolvido em clorofórmio $(25 \mathrm{~mL})$, em agitador magnético por $24 \mathrm{~h}$. Ao final deste processo, a solução foi vertida em placa de Petri com tampa, contendo 0,01875 g de NCCB desidratados por liofilização, formando solução $3 \%(\mathrm{~m} / \mathrm{v})$ e correspondendo a 2,5 \% de reforço. Simultaneamente, para o filme reforçado com $5 \%$ de NCCB, o PLLA $(0,71 \mathrm{~g})$ foi dissolvido em clorofórmio $(25 \mathrm{~mL})$, em agitador magnético por $24 \mathrm{~h}$. Ao final deste processo, a solução foi vertida em placa de Petri 
com tampa, contendo 0,0375 g de NCCB desidratados por liofilização, formando solução $3 \%$ (m/v) e correspondendo a $5 \%$ de reforço.

As soluções foram mantidas em capela de exaustão de gases por 48 h, em temperatura ambiente, para a secagem lenta do solvente e formação de filmes.

Após a evaporação do solvente, os filmes foram secos em estufa a vácuo (de marca Nova Ética), a 30 ${ }^{\circ} \mathrm{C}$, sob pressão de $400 \mathrm{~mm}$ de $\mathrm{Hg}$, por $24 \mathrm{~h}$ e armazenados em dessecador.

- Método II: utilizando NCCB funcionalizados

Para este método, uma funcionalização dos NCCB foi realizada, afim de se buscar uma maior afinidade entre PLLA e NCCB, já que os nanocristais possuem grupos hidroxila em sua superfície, que os tornam com elevado grau de polaridade e incompatíveis com matrizes de baixa polaridade, como matriz de PLLA, ou apolares. O segundo motivo que incentivou a funcionalização foi a esperada minimização do caráter hidrofílico dos NCCB, o que, conforme PARIZE [16], reduz a absorção de umidade.

Soluções contendo $0,02 \mathrm{~g}$ e $0,04 \mathrm{~g}$ de NCCB foram preparadas e submetidas a um processo de troca de solventes por imersão, sequencialmente em acetona, etanol e clorofórmio, conforme a metodologia de ROSA [17]. Para este método, foram realizadas três centrifugações a $8000 \mathrm{rpm}$ para auxiliar na troca de solvents.

Para a primeira centrifugação, dois tubos falcons contendo respectivamente 0,02 g e 0,04 g de NCCB em solução de água destilada, após serem retirados da membrana de diálise, foram centrifugados por $10 \mathrm{~min}$. Para a segunda centrifugação, os precipitados resultantes da primeira centrifugação foram imersos em acetona e, após $2 \mathrm{~h}$, centrifugados por mais $10 \mathrm{~min}$. E para a terceira centrifugação, os precipitados resultantes da segunda centrifugação foram imersos em etanol e, após $2 \mathrm{~h}$, centrifugados por mais 10 min.

Os precipitados da terceira centrifugação foram imersos em $5 \mathrm{~mL}$ de clorofórmio, em agitador magnético por $24 \mathrm{~h}$. Simultaneamente, duas soluções contendo PLLA com massas de 0,73 g e 0,71 g foram dissolvidas em clorofórmio $(20 \mathrm{~mL})$, em agitador magnético por $24 \mathrm{~h}$.

Para a produção do filme contendo 2,5\% de reforço, 0,02 g de NCCB imersos em $5 \mathrm{~mL}$ de clorofórmio foram vertidos em recipiente contendo $0,73 \mathrm{~g}$ de PLLA dissolvidos em $20 \mathrm{~mL}$ de clorofórmio, originando solução $3 \%(\mathrm{~m} / \mathrm{v})$. Posteriormente, a mistura foi submetida à sonificação, em banho de ultrassom (de marca Thornton) por 30 min, seguindo a metodologia proposta por MAZUR [1].

Para a produção do filme contendo $5 \%$ de reforço, 0,04 g de NCCB imersos em $5 \mathrm{~mL}$ de clorofórmio foram vertidos em recipiente contendo $0,71 \mathrm{~g}$ de PLLA dissolvidos em $20 \mathrm{~mL}$ de clorofórmio, originando solução $3 \%(\mathrm{~m} / \mathrm{v})$. Posteriormente, a mistura foi submetida à sonificação em banho de ultrassom por $30 \mathrm{~min}$.

As soluções foram vertidas em placa de Petri com tampa e mantidas em capela de exaustão de gases por 48 h, em temperatura ambiente, para a secagem lenta do solvente e formação de filmes.

\subsection{Caracterização dos bionanocompósitos}

As técnicas de caracterização dos bionanocompósitos foram realizadas com a finalidade de comparar as propriedades entre os polímeros e aplicadas em quatro filmes de PLLA, reforçados com NCCB, obtidos de acordo com a melhor condição definida, em proporções de 2,5 e 5 \%, preparados por dois diferentes métodos. Para melhor caracterização, um filme de PLLA puro também foi utilizado nas técnicas.

A caracterização foi feita utilizando técnicas de análise termogravimétrica (TGA) e calorimetria exploratória diferencial (DSC), no laboratório de Materiais da UNIVILLE.

A análise termogravimétrica foi realizada para a avaliação da estabilidade térmica dos bionanocompósitos de NCCB em diferentes concentrações, incorporados em PLLA, por dois métodos diferentes. Esta análise consistiu em uma técnica destrutiva, que envolveu a medida da variação de massa das amostras em estado sólido em função da temperatura, em um determinado intervalo de tempo. O aumento da temperatura provocou diferentes eventos térmicos e, consequentemente, a redução de massa das amostras, devido à formação de produtos voláteis. O equipamento utilizado para a análise foi o TGA-Q50, (de marca TA Instruments), sob atmosfera inerte de N2. Cada amostra foi inserida no porta-amostras e aquecida de 25$1000^{\circ} \mathrm{C}$, a uma taxa de aquecimento de $10^{\circ} \mathrm{C} / \mathrm{min}$. Os parâmetros experimentais foram ajustados no software TA Universal Analysis e representados graficamente para interpretação.

A análise de calorimetria exploratória diferencial foi realizada para a avaliação da quantidade de calor absorvido e liberado pelos bionanocompósitos durante a ocorrência de eventos térmicos. Esta análise consistiu na identificação da temperatura de transição vítrea $\left(T_{g}\right)$, de cristalização $\left(T_{c}\right)$, de fusão $\left(T_{m}\right)$ e grau de cristalinidade $\left(\mathrm{X}_{\mathrm{c}}\right)$. Para o cálculo de grau de cristalinidade $\left(\mathrm{X}_{\mathrm{c}}\right)$, a Equação 1 foi utilizada: 


$$
\mathrm{X}_{\mathrm{c}}=\frac{\Delta \mathrm{H}_{\mathrm{m}}}{\Delta \mathrm{H}_{\mathrm{m}}^{\circ}} \times 100 \%
$$

Onde:

$\mathrm{Xc}=$ grau de cristalinidade

$\Delta \mathrm{H}_{\mathrm{m}}=$ entalpia de fusão experimental $(\mathrm{J} / \mathrm{g})$

$\Delta \mathrm{H}_{\mathrm{m}}^{0}=$ entalpia de fusão supondo polímero $100 \%$ cristalino $(\mathrm{J} / \mathrm{g})=93,6 \mathrm{~J} / \mathrm{g}$ (valor padrão)

Fonte: MAZUR, 2012.

O equipamento utilizado para a análise foi o DSC-Q20 (de marca TA Instruments), sob fluxo de nitrogênio. Um material de referência foi inserido para a comparação. Cada amostra foi colocada no portaamostras, aquecida de $25-200{ }^{\circ} \mathrm{C}$. A taxa de aquecimento utilizada foi de $10{ }^{\circ} \mathrm{C} / \mathrm{min}$. Os parâmetros experimentais foram ajustados no software TA Universal Analysis e representados graficamente para interpretação.

\section{RESULTADOS E DISCUSSÃO}

\subsection{Produção de celulose bacteriana}

A Figura 2 ilustra culturas de Gluconacetobacter hansenii (a), membranas de CB sintetizadas pela bactéria e purificadas (b) e películas de CB resultantes das membranas secas em estufa (c).

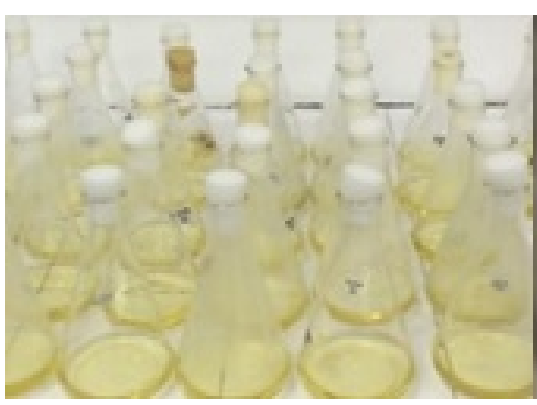

(a)

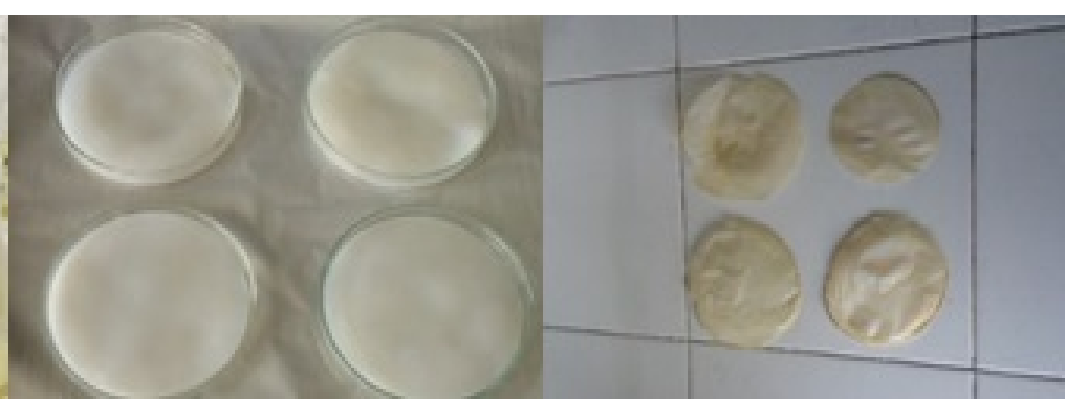

(b) (c)

Figura 2: Culturas de Gluconacetobacter hansenii (a), membranas de CB sintetizadas pela bactéria e purificadas (b) e películas de CB resultantes das membranas secas (c).

\subsection{Obtenção de nanocristais de celulose bacteriana em diferentes condições e definição de critérios}

Para a condição de hidrólise mais drástica, após a interrupção da reação com água destilada gelada, obteve-se uma suspensão de cor creme (levemente leitosa), de elevada acidez, na qual não foram observados a olho nu fragmentos de CB, indicando perda das características naturais da CB. Para as condições de hidrólise menos drásticas, os aspectos visuais foram se diferenciando.

Para os ensaios 1, 3, 5 e 7, a CB permaneceu visualmente inalterada, desta forma pode-se sugerir que não tenha sofrido ataque ácido, impossibilitando a formação de nanocristais.

Para os ensaios 9, 10 e 11, a CB deteriorou parcialmente, contudo as partículas não indicaram tamanhos em escala nanométrica.

Para o ensaio 4, a CB deteriorou quase totalmente, porém as partículas também não indicam tamanhos em escala nanométrica.

Para os ensaios 2, 6 e 8, a CB foi visivelmente alterada, indicando potenciais características de hidrólise para a formação de NCCB. 


\subsubsection{Análise termogravimétrica dos NCCB}

A Figura 3 mostra as curvas de TGA da CB pura e dos nanocristais (referente aos experimentos) e a Tabela 3 relaciona os dados determinados a partir destas curvas.

O perfil de degradação da CB mostra a ocorrência de três eventos de perda de massa. O primeiro evento térmico está associado a perda de água superficial, que ocorre no intervalo que, conforme LIMA et al. [9], compreende a temperatura ambiente $\left(\cong 30^{\circ} \mathrm{C}\right)$ até cerca de $150{ }^{\circ} \mathrm{C}$, com $5,21 \%$ de perda de massa. $\mathrm{O}$ segundo evento causa acentuada perda de massa e é atribuído à degradação da celulose, que inclui despolimerização, decomposição das unidades de glicose e desidratação. A temperatura de início de degradação extrapolada ( $\mathrm{T}_{\text {onset } 2}$ ) igual a $301,9^{\circ} \mathrm{C}$ e a temperatura na qual a taxa de degradação é máxima $\left(\mathrm{T}_{\max 2}\right)$ igual a $337,5^{\circ} \mathrm{C}$, com perda de massa de $61,97 \%$, corrobora com valores citados na literatura [9]. $\mathrm{O}$ terceiro e último evento representa a degradação de resíduos carbonáceos, que se estende até cerca de $500^{\circ} \mathrm{C}$, com perda de massa de $24,78 \%$, dados que também confirmam o que a literatura reporta [18]. O resíduo carbonáceo final observado foi de 7,37\%.

Segundo TAIPINA (2012), os NCCB possuem cristalinidade superior à cristalinidade da amostra de CB não hidrolisada, utilizada na análise. Quanto maior a cristalinidade da celulose, maior é a temperatura de decomposição térmica, devido ao menor teor de componente amorfo. No entanto, outros fatores também podem exercer influência na estabilidade térmica. Sabe-se que a hidrólise com ácido sulfúrico influencia negativamente na estabilidade térmica dos nanocristais, visto que a temperatura em que se inicia a perda de massa é diminuída. Isto ocorre, pois, os grupos sulfatos exercem efeito catalítico nas reações de desidratação da celulose [10]. Estes diferentes fatores que exercem influência na estabilidade térmica dos nanocristais prejudicam a visualização de uma tendência que era esperada a ser observada graficamente.

Os picos mais acentuados, que representam o terceiro evento térmico, observados nas curvas de DTG, correspondem às amostras de NCCB com forte interação com o ácido sulfúrico, o que favorece a degradação termo-oxidativa do carbono em altas temperaturas [18].

Tabela 3. Dados da análise termogravimétrica da CB pura e dos NCCB (referentes aos experimentos).

\begin{tabular}{|c|c|c|c|c|c|c|c|c|c|}
\hline EXP & $\begin{array}{l}\text { Condições de } \\
\text { hidrólise: } \\
\text { [ ] de ácido / } \\
\text { Temperatura / } \\
\text { Tempo }\end{array}$ & $\begin{array}{l}\text { Perda } \\
\text { de } \\
\text { massa } 1 \\
(\%)\end{array}$ & $\begin{array}{l}T_{\text {onset } 2} \\
\left({ }^{\circ} \mathrm{C}\right)\end{array}$ & $\begin{array}{l}\text { Perda } \\
\text { de } \\
\text { massa } 2 \\
(\%)\end{array}$ & $\begin{array}{l}T_{\max 2} \\
\left({ }^{\circ} \mathrm{C}\right)\end{array}$ & $\begin{array}{l}\mathbf{T}_{\text {onset } 3} \\
\left({ }^{\circ} \mathbf{C}\right)\end{array}$ & $\begin{array}{l}\text { Perda } \\
\text { de } \\
\text { massa } 3 \\
(\%)\end{array}$ & $\begin{array}{l}\mathbf{T}_{\max 3} \\
\left({ }^{\circ} \mathbf{C}\right)\end{array}$ & $\begin{array}{l}\text { Resíduo } \\
\text { (\%) }\end{array}$ \\
\hline & CB pura & 5,21 & 301,9 & 61,97 & 337,5 & -- & 24,78 & -- & 7,37 \\
\hline 1 & $50 \% / 40^{\circ} \mathrm{C} / 20 \min$ & 4,33 & 302,1 & 69,29 & 330,3 & 559,9 & 15,42 & 614,5 & 10,86 \\
\hline 2 & $80 \% / 40^{\circ} \mathrm{C} / 20 \mathrm{~min}$ & 5,86 & 277,5 & 77,57 & 309,4 & 477,8 & 15,80 & 527,7 & 0,04 \\
\hline 3 & $50 \% / 60^{\circ} \mathrm{C} / 20 \min$ & 5,31 & 321,2 & 69,80 & 354,1 & 551,4 & 16,20 & 607,2 & 8,27 \\
\hline 4 & $80 \% / 60^{\circ} \mathrm{C} / 20 \mathrm{~min}$ & 4,44 & 249,4 & 73,90 & 322,8 & 554,9 & 18,10 & 618,4 & 3,51 \\
\hline 5 & $50 \% / 40^{\circ} \mathrm{C} / 60 \min$ & 6,00 & 289,1 & 60,10 & 325,9 & 477,0 & 26,88 & 524,3 & 7,00 \\
\hline 6 & $80 \% / 40^{\circ} \mathrm{C} / 60 \mathrm{~min}$ & 6,70 & 235,2 & 57,20 & 299,7 & 343,5 & 22,55 & 416,3 & 13,48 \\
\hline 7 & $50 \% / 60^{\circ} \mathrm{C} / 60 \mathrm{~min}$ & 3,75 & 275,4 & 82,28 & 304,9 & 519,4 & 16,32 & 519,4 & 0,00 \\
\hline 8 & $80 \% / 60^{\circ} \mathrm{C} / 60 \min$ & 3,40 & 239,2 & 54,52 & 275,7 & 343,5 & 24,93 & 363,7 & 16,96 \\
\hline 9 & $65 \% / 50^{\circ} \mathrm{C} / 40 \mathrm{~min}$ & 3,75 & 270,7 & 82,05 & 295,1 & 560,0 & 7,21 & 560,4 & 6,40 \\
\hline 10 & $65 \% / 50^{\circ} \mathrm{C} / 40 \mathrm{~min}$ & 5,05 & 266,5 & 70,33 & 292,3 & 475,2 & 18,98 & 529,1 & 5,68 \\
\hline 11 & $65 \% / 50^{\circ} \mathrm{C} / 40 \mathrm{~min}$ & 4,33 & 265,7 & 74,69 & 291,3 & 482,6 & 4,6 & 629,3 & 16,27 \\
\hline
\end{tabular}




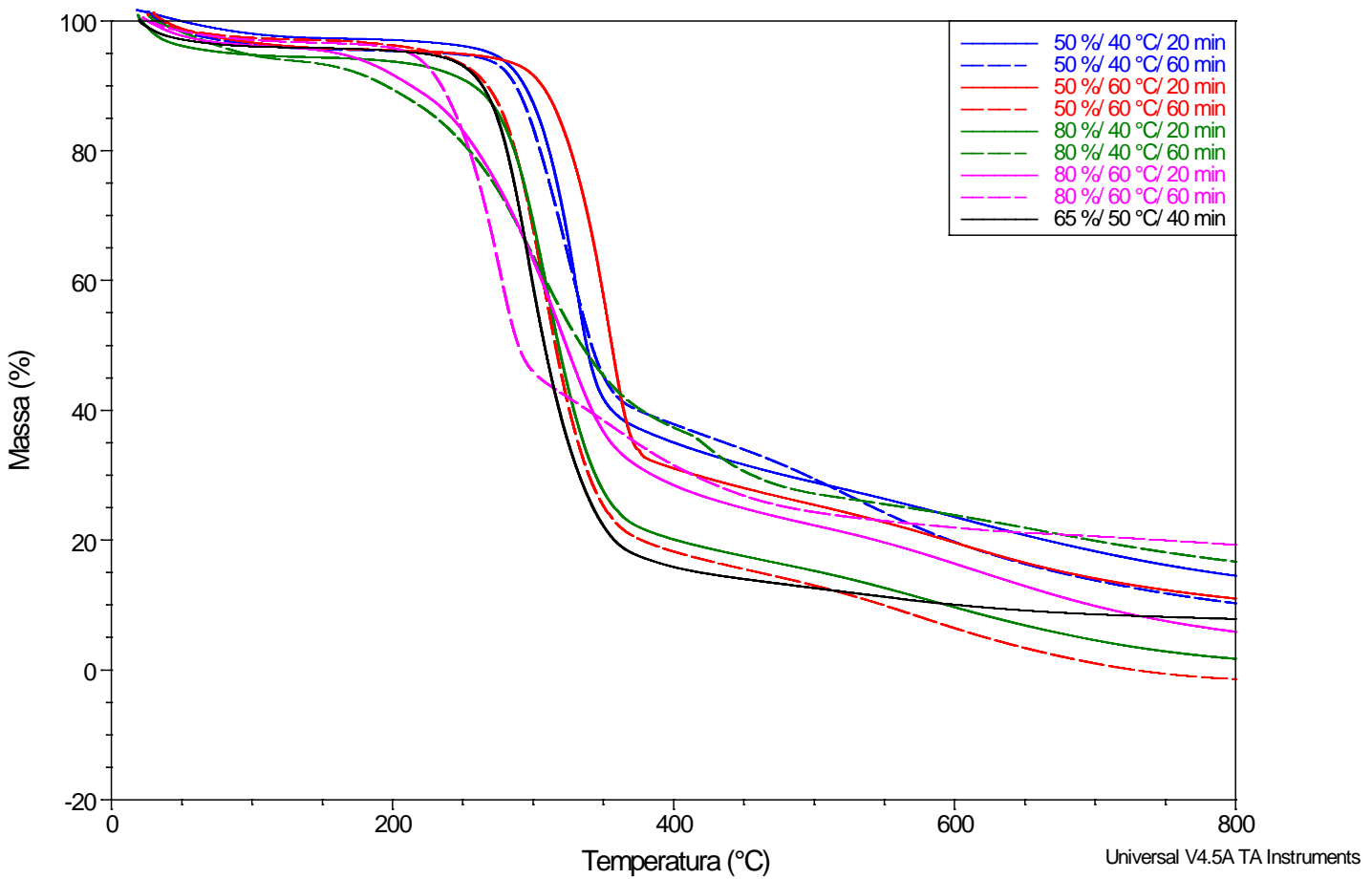

(a)

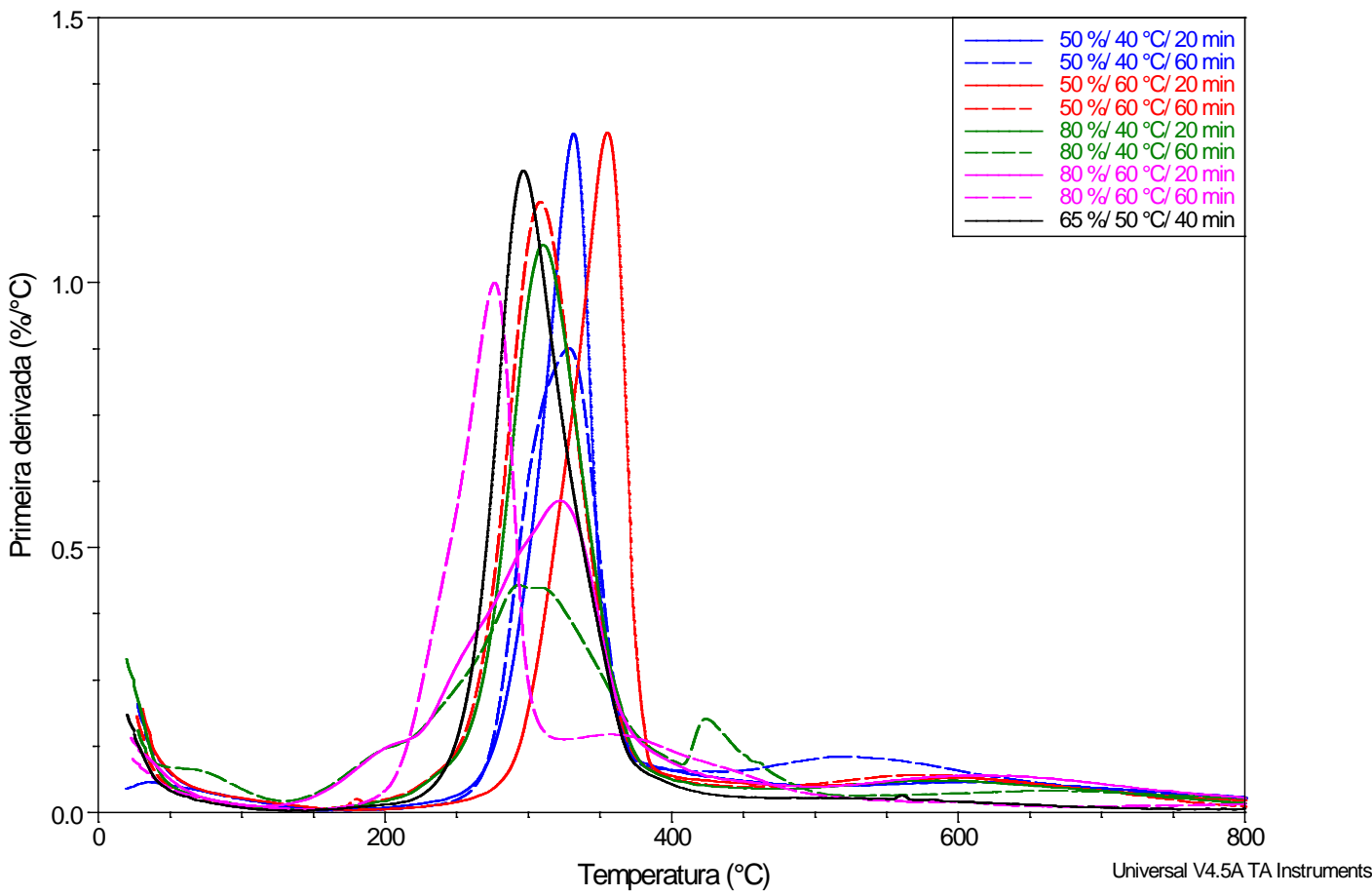

(b)

Figura 3: Curvas de TGA (a) e DTG (b) da CB pura e dos nanocristais (referentes aos experimentos). 
Diante do planejamento proposto, a fim de complementar o estudo termogravimétrico referente à degradação da celulose, foi realizada uma análise estatística de variância (ANOVA), com o objetivo de identificar as variáveis independentes significativas para o processo. Foram obtidos resultados significativos

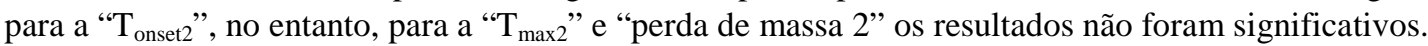

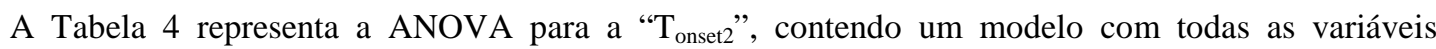
independentes e as interações de primeiro nível, utilizando o erro padrão (erro SS). São apresentados valores de soma quadrática, grau de liberdade, média quadrática, F calculado e probabilidade de valores serem significativos (p-valor). Valores de p menores que 0,05 indicam que as variáveis testadas são significativas.

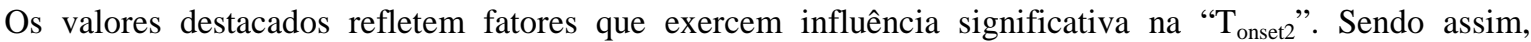
verificou-se que das variáveis independentes testadas, quando analisadas individualmente, apenas a temperatura de hidrólise não exerce influência significativa na " $\mathrm{T}_{\text {onset2 }}$ ". Entretanto, a concentração de ácido e o tempo de hidrólise exercem influência significativa. Nesta análise, nenhuma interação entre fatores foi significativa na " $\mathrm{T}_{\text {onset2 }}$ ", por este motivo foram excluídas do modelo, conforme pode ser observado na Tabela 5.

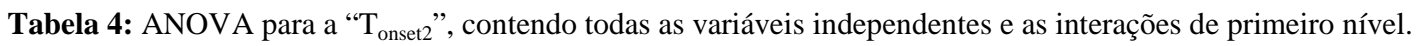

\begin{tabular}{l|l|l|l|l|l}
\hline FATORES & $\begin{array}{l}\text { SOMAS DOS } \\
\text { QUADRADOS }\end{array}$ & $\begin{array}{l}\text { GRAUS DE } \\
\text { LIBERDADE }\end{array}$ & $\begin{array}{l}\text { MÉDIAS DOS } \\
\text { QUADRADOS }\end{array}$ & F CALC $^{\text {PU-VALOR }}$ \\
\hline$*(1)$ [ ] de ácido (\%) & 4347,781 & 1 & 4347,781 & 28,06910 & 0,006095 \\
\hline (2) Temperatura $\left({ }^{\circ} \mathrm{C}\right)$ & 43,711 & 1 & 43,711 & 0,28220 & 0,623393 \\
\hline$*(3)$ Tempo (min) & 1548,461 & 1 & 1548,461 & 9,99680 & 0,034126 \\
\hline$(1),(2)$ & 108,781 & 1 & 108,781 & 0,70229 & 0,449171 \\
\hline$(1),(3)$ & 4,961 & 1 & 4,961 & 0,03203 & 0,866662 \\
\hline$(2),(3)$ & 0,061 & 1 & 0,061 & 0,00040 & 0,985087 \\
\hline Erro & 619,583 & 4 & 154,896 & - & - \\
\hline Total SS & 6673,340 & 10 & - & - & - \\
\hline
\end{tabular}

* fatores que exercem influência significativa na “ $\mathrm{T}_{\text {onset2 }}$ ”.

Tabela 5: ANOVA para a “ $\mathrm{T}_{\text {onset2 }}$ ”, sem as interações entre fatores.

\begin{tabular}{l|l|l|l|l|l}
\hline FATORES & $\begin{array}{l}\text { SOMAS DOS } \\
\text { QUADRADOS }\end{array}$ & $\begin{array}{l}\text { GRAUS DE } \\
\text { LIBERDADE }\end{array}$ & $\begin{array}{l}\text { MÉDIAS DOS } \\
\text { QUADRADOS }\end{array}$ & F $_{\text {CALC }}$ & P-VALOR \\
\hline$*$ (1) [ ] de ácido (\%) & 4347,781 & 1 & 4347,781 & 41,49855 & 0,000353 \\
\hline (2) Temperatura $\left({ }^{\circ} \mathrm{C}\right)$ & 43,711 & 1 & 43,711 & 0,41721 & 0,538921 \\
\hline$*(3)$ Tempo (min) & 1548,461 & 1 & 1548,461 & 14,77970 & 0,006338 \\
\hline Erro & 733,386 & 7 & 104,769 & - & - \\
\hline Total SS & 6673,340 & 10 & - & - & - \\
\hline
\end{tabular}

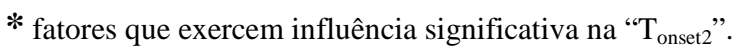

Os resultados dos coeficientes de regressão do modelo estão apresentados na Tabela 6. 
Tabela 6: Coeficientes de regressão para a “ $\mathrm{T}_{\text {onset2 }}$ ”.

\begin{tabular}{l|l|l}
\hline FATORES & COEFICIENTES DE REGRESSÃO & ERRO PADRÃO \\
\hline Média & 412,5333 & 25,20379 \\
\hline$*(1)$ [ ] de ácido $(\%)$ & $-1,5542$ & 0,24126 \\
\hline$(2)$ Temperatura $\left({ }^{\circ} \mathrm{C}\right)$ & $-0,2338$ & 0,36189 \\
\hline$*(3)$ Tempo (min) & $-0,6956$ & 0,18094 \\
\hline
\end{tabular}

* fatores que exercem influência significativa na “ $\mathrm{T}_{\text {onset2}}$ ”.

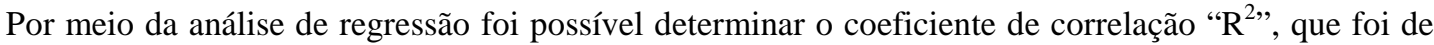
0,8901, indicando que 89,01 \% da variabilidade na resposta pode ser explicada por este modelo.

A Figura 4 exibe o gráfico de superfície de resposta 3D, representando a interação entre “[] de ácido"

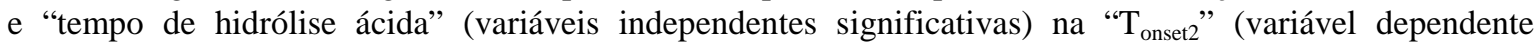
significativa), fixando a temperatura no ponto central $\left(50^{\circ} \mathrm{C}\right)$.

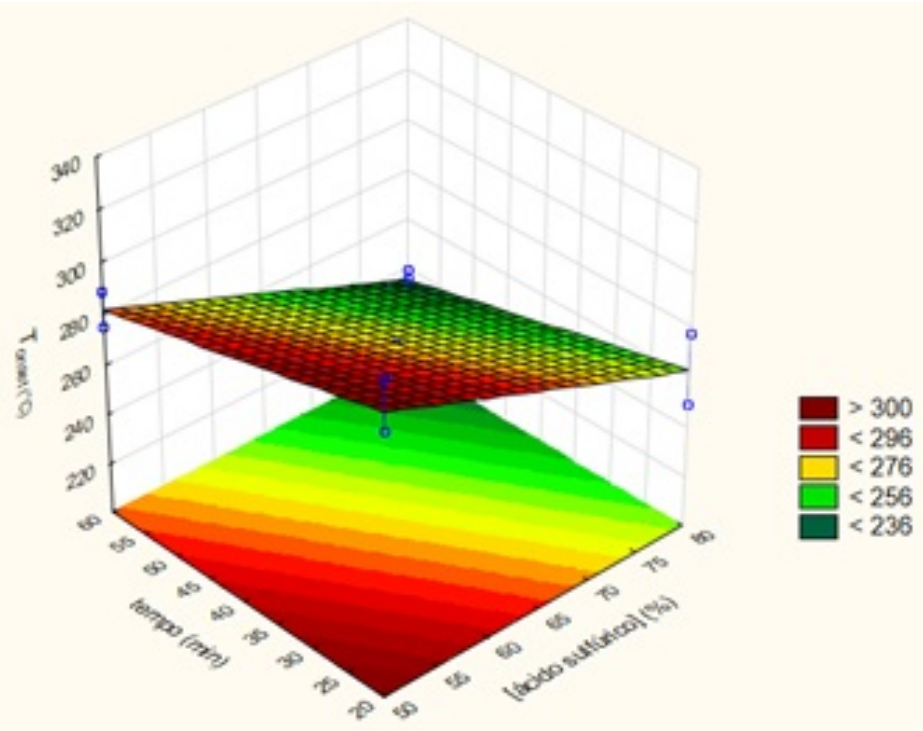

Figura 4: Gráfico de superfície de resposta representando a interação entre “[] de ácido” e "tempo de hidrólise ácida” na “ $\mathrm{T}_{\text {onset2 }}$ ", fixando a temperatura no ponto central $\left(50^{\circ} \mathrm{C}\right)$.

De acordo com o modelo apresentado na Figura 4 é possível observar que a elevada interação da CB

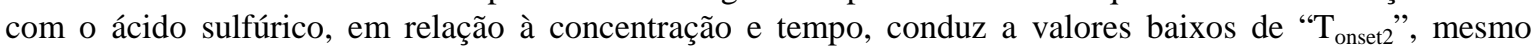
considerando um grau de cristalinidade aumentado. Esta ocorrência pode ser justificada pelo fato de a hidrólise com ácido sulfúrico influenciar negativamente a estabilidade térmica da CB, como já mencionado.

\subsubsection{Análise de espalhamento dinâmico de luz (DLS) dos NCCB}

Para a amostra 8 verificou-se a presença de três populações de tamanho: $388 \mathrm{~nm}$, em 61,7 \% da amostra; 96,36 nm, em 20,4 \% da amostra; e 1,068 $\mu \mathrm{m}$ em 17,6 \% da amostra. Predominantemente a amostra contém partículas em tamanhos nanométricos, que de acordo com a literatura são nanocristais de celulose bacteriana [19].

O potencial zeta superficial obtido foi - $38 \mathrm{mV}$, indicando suspensão estável, já que se consideram partículas estáveis em suspensão todas as partículas cujo módulo de carga do potencial zeta seja maior que 25 $\mathrm{mV}$ [20]. Esta estabilidade está relacionada com a presença de cargas negativas (grupos sulfatos) na superfície dos NCCB, ocasionando equilíbrio eletrostático decorrente das forças de repulsão entre os 
nanocristais [21].

Para as demais amostras, não foi possível a realização da análise, pois continham partículas grandes e visíveis a olho nu. O equipamento Zetasizer Nano Series trabalha com faixas específicas de tamanho.

Com base nas análises apresentadas, os NCCB obtidos conforme o experimento 8 foram escolhidos para serem incorporados ao PLLA.

\subsection{Preparação dos bionanocompósitos}

Os NCCB obtidos por hidrólise ácida, feita com ácido sulfúrico, formam suspensões aquosas estáveis, devido a presença de cargas negativas (grupos sulfatos) na superfície dos NCCB, ocasionando equilíbrio eletrostático decorrente das forças de repulsão entre os nanocristais. Porém, é válido comentar que esta característica dificilmente é mantida após a secagem dos mesmos, uma vez que as fortes interações de hidrogênio existentes favorecem a aglomeração [21].

A textura dos NCCB pode ser comparada com a textura de um aglomerado de pós finos, de coloração creme, que se constituem em fragmentos em forma de agulhas, também designados como whiskers de CB e recomendados a serem utilizados como reforços em matrizes poliméricas.

O filme de PLLA puro é incolor, transparente e de superfície lisa.

Após a adição dos NCCB, o bionanocompósito de PLLA com 2,5 \% de reforço preparado de acordo com o Método 1, apresentou-se rugoso, pode-se observar a presença de duas fases, sendo que os nanocristais se posicionaram somente na superfície inferior dos filmes, indicando que os NCCB não se dispersaram homogeneamente. Este comportamento é explicado pela falta de interação do PLLA com os NCCB, já que apresentam polaridades diferentes. A dispersão inadequada do nanoreforço na matriz polimérica, também promoveu formação de aglomerados, que atuam como pontos de concentração de tensão e podem proporcionar efeito contrário ao desejado, fragilizando o material ao invés de melhorar suas propriedades. Adequada dispersão trata-se de um desafio na formação de bionanocompósitos [22]. Comportamento similar foi observado para o bionanocompósito de PLLA com $5 \%$ de reforço de NCCB preparado também de acordo com o Método 1.

Após a adição dos NCCB, o bionanocompósito de PLLA com 2,5 \% de reforço de NCCB preparado de acordo com o Método 2, apresentou-se liso, indicando interação do PLLA-NCCB, já que para este método foi realizada uma funcionalização dos nanocristais, por meio de troca de solventes, compatibilizando em etapas a polaridade de matriz e reforço. O filme apresentou-se translúcido, com coloração intermediária entre creme (coloração dos NCCB) e incolor (característica do PLLA puro), contendo algumas partículas aglomeradas. Comportamento similar foi observado para o bionanocompósito de PLLA com $5 \%$ de reforço de NCCB preparado também de acordo com o Método 2.

Dentre os dois métodos conclui-se que o Método 2 permitiu a visualização de melhores características de adesão entre matriz e reforço.

\subsection{Caracterização dos bionanocompósitos}

\subsubsection{Análise termogravimétrica (TGA)}

A Figura 5 corresponde às curvas de TGA e DTG do PLLA puro e dos bionanocompósitos reforçados com 2,5 e $5 \%$ de NCCB, preparados de acordo com o Método 1 (NCCB desidratados) (a) e as curvas de TGA e DTG do PLLA puro e dos bionanocompósitos reforçados com 2,5 e $5 \%$ de NCCB, preparados de acordo com o Método 2 (NCCB submetidos à troca de solventes por imersão) (b). A Tabela 7 relaciona os dados determinados a partir destas curvas.

O perfil de degradação do PLLA mostra a ocorrência de dois eventos de perda de massa. O primeiro evento térmico é atribuído à perda de água superficial, de aproximadamente $5 \%$. Este percentual aumenta em função do aumento do teor de NCCB na amostra, chegando a $8 \%$ e 8,1 \%, com adição de $5 \%$ de reforço para os Métodos 1 e 2, respectivamente. Isso se deve ao fato de a celulose bacteriana ser um polímero com alta higroscopicidade [6].

O segundo evento, que causa acentuada perda de massa, é atribuído à degradação do PLLA e ocorre com temperatura de início de degradação extrapolada $\left(\mathrm{T}_{\text {onset2 }}\right)$ em $319,8{ }^{\circ} \mathrm{C}$ e temperatura na qual a taxa de degradação é máxima $\left(T_{\max 2}\right)$ em $339,5{ }^{\circ} \mathrm{C}$, com $85,2 \%$ de perda de massa. Os valores da $T_{\text {onset }}$ e da $T_{\max }$ estão inferiores aos encontrados na literatura $\left(335^{\circ} \mathrm{C}\right.$ e $407^{\circ} \mathrm{C}$ respectivamente). Esta diferença pode ser explicada pela diferença de característica do material utilizado, como por exemplo a massa molar do 
polímero, que afeta diretamente suas características [1]. Para os bionanocompósitos preparados pelo Método 1, houve uma diminuição de 3,3 ${ }^{\circ} \mathrm{C}$ na $\mathrm{T}_{\text {onset2 }}$ para a amostra com adição de 2,5 \% de NCCB e um pequeno aumento de 2,9 ${ }^{\circ} \mathrm{C}$ para a amostra com $5 \%$ de NCCB. Para os bionanocompósitos preparados pelo Método 2 , houve aumento na $\mathrm{T}_{\text {onset2 }}$, conforme o aumento do teor de NCCB, chegando a um incremento de $10,4{ }^{\circ} \mathrm{C}$ para as amostras com $5 \%$ de reforço.

O pequeno pico observado para amostra PLLA/NCCB 5 \% (Método 1), que representa o terceiro estágio de degradação, com $\mathrm{T}_{\text {onset }}$ bastante inferior ao estágio de decomposição do PLLA, corresponde a decomposição dos NCCB incorporados ao filme.

Dentre os dois métodos conclui-se que o Método 2 permitiu uma melhoria da estabilidade térmica do polímero.

Tabela 7: Dados da análise termogravimétrica do PLLA puro e dos bionanocompósitos reforçados com NCCB, preparados pelos Métodos 1 e 2.

\begin{tabular}{l|l|l|l|l|l|l|l}
\hline AMOSTRAS & MÉTODO & $\begin{array}{l}\text { PERDA DE } \\
\text { MASSA 1 } \\
(\%)\end{array}$ & $\begin{array}{l}\mathbf{T}_{\text {ONSET2 }} \\
\left({ }^{\circ} \mathbf{C}\right)\end{array}$ & $\begin{array}{l}\text { PERDA DE } \\
\text { MASSA 2 } \\
(\%)\end{array}$ & $\begin{array}{l}\mathbf{T}_{\text {MAX2 }} \\
\left({ }^{\circ} \mathbf{C}\right)\end{array}$ & $\begin{array}{l}\mathbf{T}_{\text {ONSET3 }} \\
\left({ }^{\circ} \mathbf{C}\right)\end{array}$ & $\begin{array}{l}\mathbf{T}_{\text {MAX3 }} \\
\left({ }^{\circ} \mathbf{C}\right)\end{array}$ \\
\hline PLLA puro & --- & 5,0 & 319,8 & 85,2 & 339,5 & --- & --- \\
\hline PLLA/NCCB 2,5 \% & M1 & 7,8 & 316,5 & 92,5 & 341,2 & --- & --- \\
\hline PLLA/NCCB 5,0 \% & M1 & 8,0 & 322,7 & 85,1 & 351,0 & 237,1 & 276,9 \\
\hline PLLA/NCCB 2,5 \% & M2 & 7,5 & 328,6 & 94,7 & 348,2 & --- & -- \\
\hline PLLA/NCCB 5,0 \% & M2 & 8,1 & 330,2 & 90,2 & 348,1 & --- & -- \\
\hline
\end{tabular}




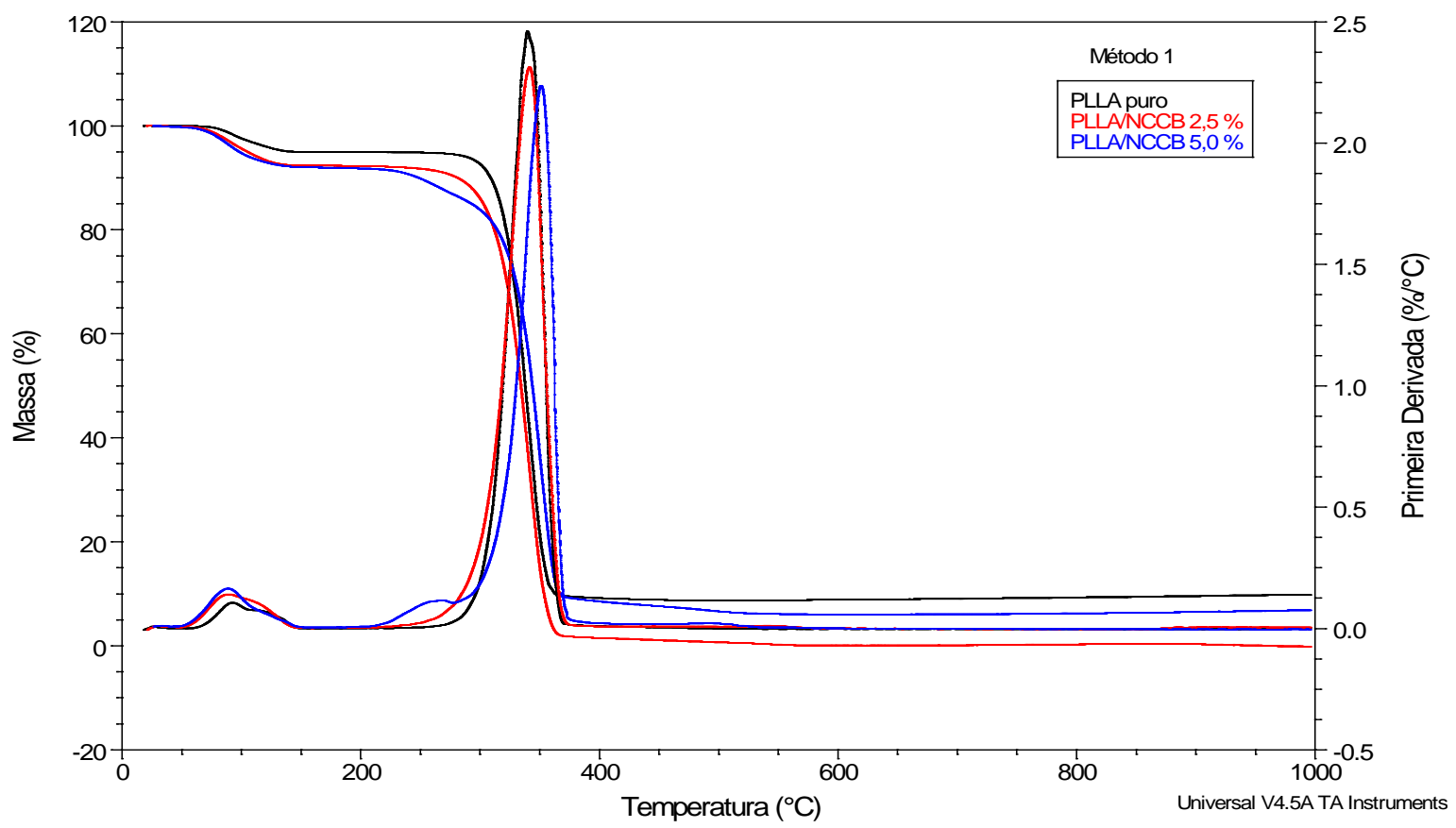

(a)

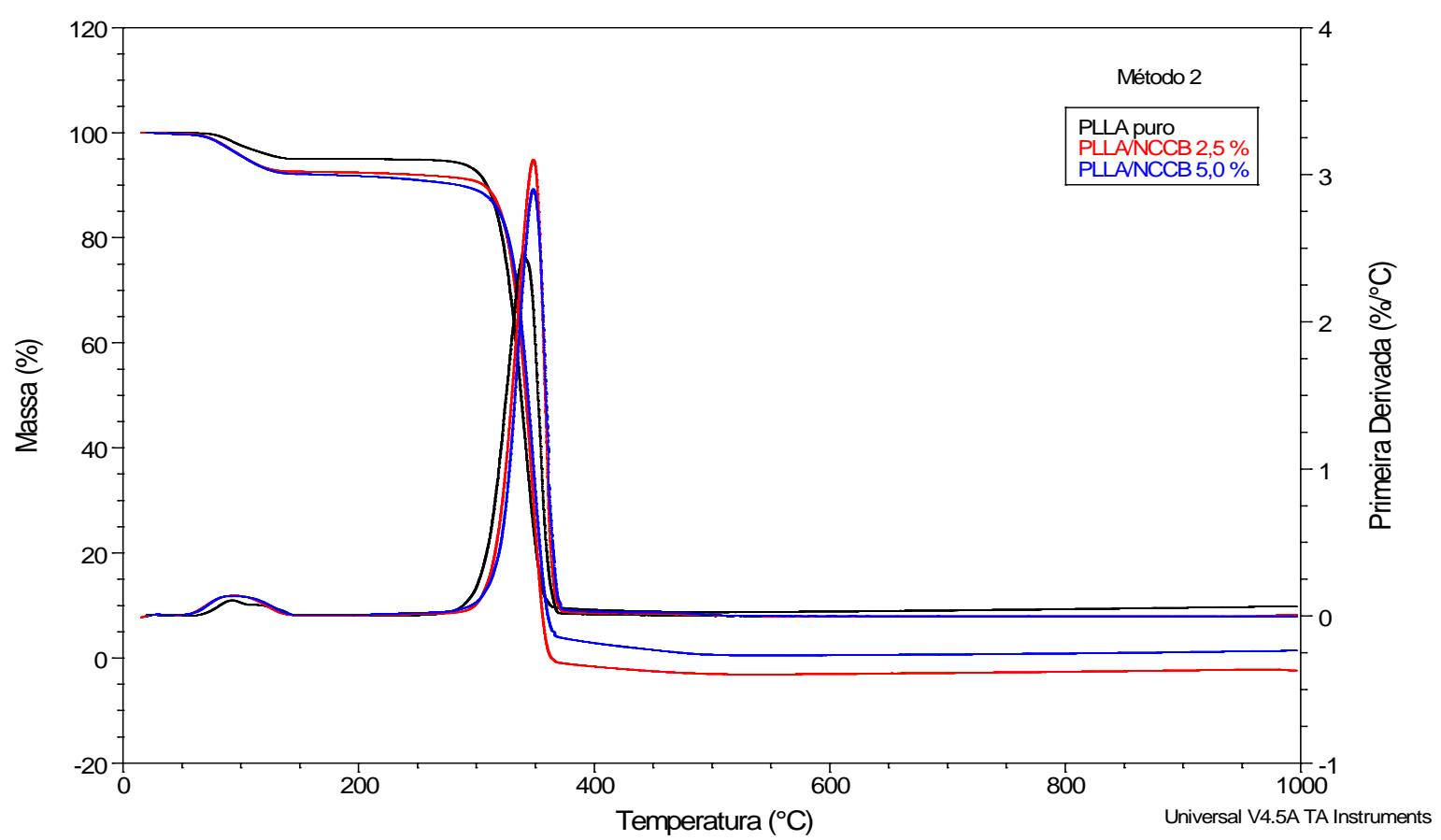

(b)

Figura 5: Curvas de TGA (a) e DTG (b) do PLLA puro e dos bionanocompósitos reforçados com NCCB, preparados pelo Método 1 (a) e pelo Método 2 (b).

\subsubsection{Calorimetria explanatória diferencial (DSC)}

A Figura 6 corresponde às curvas de DSC do PLLA puro e dos bionanocompósitos reforçados com 2,5 e 5 \% de NCCB, preparados de acordo com o Método 1 (NCCB desidratados) e dos bionanocompósitos reforçados com 2,5 e 5 \% de NCCB, preparados de acordo com o Método 2 (NCCB funcionalizados). A Tabela 8 relaciona os dados determinados a partir destas curvas.

Para o PLLA puro observou-se a temperatura de transição vítrea $\left(\mathrm{T}_{\mathrm{g}}\right)$ em $46,1{ }^{\circ} \mathrm{C}$, a temperatura de cristalização $\left(T_{c}\right)$ em $102,1{ }^{\circ} \mathrm{C}$ e a presença de duas temperaturas de fusão $\left(T_{m}\right)$, sendo a primeira em $137,4^{\circ} \mathrm{C}$ e o segunda em $145,3^{\circ} \mathrm{C}$. A presença de dois picos de fusão está relacionado a cristais de tamanho 
diferentes, sendo que os cristais menores fundem a uma temperatura menor e os cristais maiores fundem a uma temperatura maior. A entalpia de fusão encontrada foi de 37,8 J/g, que corresponde a 40,38 \% de cristalinidade. Estes dados concordam com a literatura [1,11].

Independentemente do método utilizado e do porcentual de reforço adicionado, para os bionanocompósitos observou-se uma diminuição da $T_{\mathrm{g}}$. A $\mathrm{T}_{\mathrm{g}}$ está relacionada com a movimentação de segmentos das cadeias poliméricas e neste caso indica que a adição dos NCCB aumentou a flexibilidade do PLLA. Este aumento de flexibilidade pode ser explicado pelo elevado módulo elástico dos nanocristais de celulose (de aproximadamente $140 \mathrm{GPa}$ ) e pela alteração no arranjo microestrutural das cadeias poliméricas, devido à influência da presença de nanocristais [23].

A quantidade adicionada de NCCB não alterou significativamente a $T_{c}$ e $T_{m}$, independentemente do método de preparação dos filmes e do porcentual de NCCB adicionado.

O grau de cristalinidade diminuiu com a adição de NCCB.

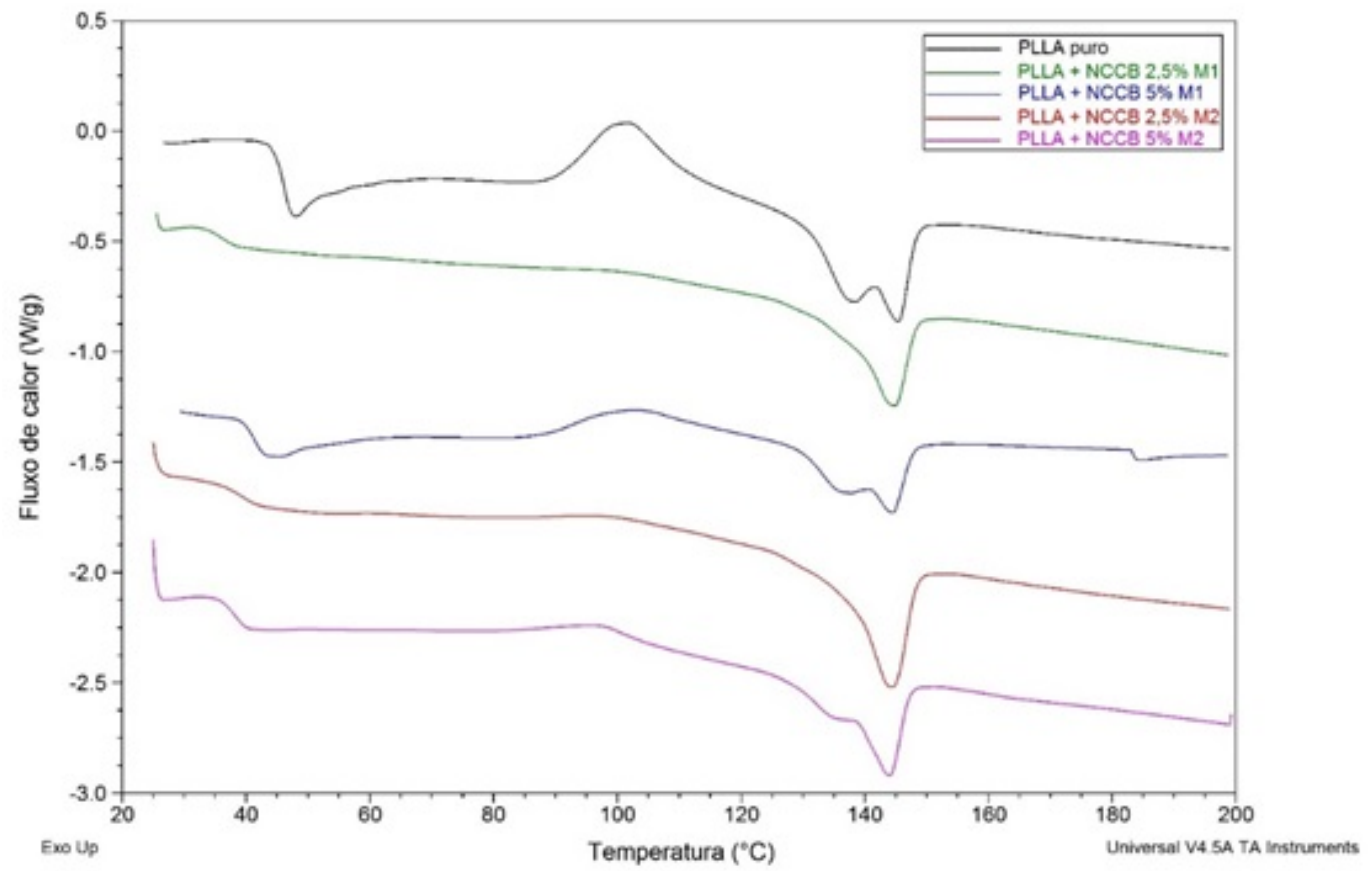

Figura 6: Curvas de DSC do PLLA puro e dos bionanocompósitos reforçados com NCCB, preparados pelo Método 1 e pelo Método 2.

Tabela 8. Dados da análise de TGA do PLLA puro e dos bionanocompósitos reforçados com NCCB, preparados pelos Métodos 1 e 2.

\begin{tabular}{l|l|l|l|l|l|l}
\hline AMOSTRAS & $\mathbf{M E ́}$ TODO & $\mathbf{T}_{\mathbf{G}}\left({ }^{\mathbf{0}} \mathbf{C}\right)$ & $\mathbf{T}_{\mathbf{C}}\left({ }^{\mathbf{0}} \mathbf{C}\right)$ & $\mathbf{T}_{\mathbf{M}}\left({ }^{\mathbf{0}} \mathbf{C}\right)$ & $\Delta \mathbf{H m}(\mathbf{J} / \mathbf{G})$ & $\mathbf{X}_{\mathbf{C}}(\mathbf{\%})$ \\
\hline PLLA puro & --- & 46,1 & 102,1 & $\begin{array}{l}137,4 ; \\
145,3\end{array}$ & 37,80 & 40,38 \\
\hline $\begin{array}{l}\text { PLLA/NCCB } \\
2,5 \%\end{array}$ & M1 & 35,7 & - & 144,6 & 23,90 & 25,53 \\
\hline $\begin{array}{l}\text { PLLA/NCCB } \\
5 \%\end{array}$ & M1 & 41,3 & 102,7 & $\begin{array}{l}137,1 \\
144,5\end{array}$ & 22,98 & 24,55 \\
\hline $\begin{array}{l}\text { PLLA/NCCB } \\
2,5 \%\end{array}$ & M2 & 38,9 & - & 144,1 & 31,46 & 33,61 \\
\hline $\begin{array}{l}\text { PLLA/NCCB } \\
5 \%\end{array}$ & M2 & 38,5 & 97,3 & $\begin{array}{l}143,9 \\
135,3\end{array}$ & 23,15 & 24,73 \\
\hline
\end{tabular}

Onde:

$\mathrm{T}_{\mathrm{g}}=$ temperatura de transição vítrea ; $\mathrm{T}_{\mathrm{c}}=$ temperatura de cristalização; $\mathrm{T}_{\mathrm{m}}=$ temperatura de fusão; $\Delta \mathrm{Hm}=$ entalpia de fusão; $\mathrm{X}_{\mathrm{c}}=$ grau de cristalinidade. 


\section{CONCLUSÕES}

Os resultados obtidos mostram que foi possível a obtenção de NCCB, sob condições específicas de hidrólise ácida. Foi possível também a incorporação destes NCCB como reforço em matriz de PLLA, um polímero de produção comercial assegurada.

A produção de membranas de CB foi garantida por meio da bactéria $G$. hansenii, em cultura estática.

Dentre os ensaios planejados, a obtenção de NCCB por hidrólise ácida foi eficiente nas condições: $80 \%$ de concentração de ácido sulfúrico $(\mathrm{m} / \mathrm{m}), 60{ }^{\circ} \mathrm{C}$ e 60 min.

Quando em suspensão, os NCCB (obtidos conforme as condições de hidrólise destacadas) apresentaram carga de potencial zeta superficial adequada $(-38 \mathrm{mV})$, indicando estabilidade eletrostática favorável, relacionada à presença de cargas negativas na superfície das partículas, o que causa repulsão entre os NCCB.

Os bionanocompósitos preparados por meio do Método 2 (após funcionalização dos NCCB, por troca de solventes) mostraram visivelmente uma melhor afinidade entre matriz e reforço. Este comportamento ocorreu, pois, a troca de solventes provocou uma redução no caráter hidrofílico dos NCCB e compatibilizou características de polaridade entre matriz e reforço, reforçando a teoria que incentiva a funcionalização da superfície de NCCB, compreendida como foco principal para promover melhoria de dispersão entre meios hidrofílicos e hidrofóbicos.

Os resultados de TGA indicam que os bionanocompósitos preparados por meio do Método 2 possuem melhor estabilidade térmica quando comparados ao PLLA puro, chegando ao incremento de $10,4{ }^{\circ} \mathrm{C}$ na $\mathrm{T}_{\text {onset } 2}$, para amostras com $5 \%$ de reforço. Os resultados de TGA também indicam que os bionanocompósitos preparados por meio do Método 2 apresentam melhor estabilidade térmica quando comparados aos bionanocompósitos preparados por meio do Método 1 , chegando ao incremento de $7,5{ }^{\circ} \mathrm{C}$ na $\mathrm{T}_{\text {onset2}}$, para amostras com $5 \%$ de reforço.

Os resultados de DSC indicam que independentemente do método utilizado para a preparação dos bionanocompósitos e do porcentual de reforço adicionado, observou-se a diminuição da $T_{g}$, ou seja, houve um aumento na flexibilidade do PLLA, explicado pelo elevado módulo elástico nos NCCB. O grau de cristalinidade diminuiu com a adição de NCCB.

\section{AGRADECIMENTOS}

À CAPES, pelo apoio financeiro.

\section{BIBLIOGRAFIA}

[1] MAZUR, L.P. "Preparação e caracterização de nanocompósitos de poli (L-ácido láctico) e diferentes argilas organofílicas”, Dissertação de M.Sc., UNIVILLE, Joinville, SC, Brasil, 2012.

[2] DONINI, I.A.N., SALVI, D.T.B., FUKUMOTO, F.K., et al., "Biossíntese e recentes avanços na produção de celulose bacteriana”, Eclética Química, v. 35, n. 4, pp. 165-178, 2010.

[3] ERENO, Dinorah, PESQUISA FAPESP,

http://revistapesquisa.fapesp.br/wpcontent/uploads/2004/07/070-073-biotecnologia.pdf?b393b6. Acessado em setembro de 2017.

[4] ROITMAN, T., ALMEIDA, L.F.M., ROITMAN, T., et al., "Monitoramento tecnológico e mercadológico de biopolímeros”, Polímeros - Ciência e Tecnologia, v. 18, n. 3, pp. 256-261, 2008.

[5] SILVA, D.J., D’ALMEIDA, M.L. “Nanocristais de celulose”, O Papel, v. 70, n. 7, pp. 34-52, 2009.

[6] BARUD, H.S., Novos materiais multifuncionais baseados em celulose bacteriana, Tese de D.Sc., UNIARA, Araraquara, SP, Brasil, 2010.

[7] CIRIGO PÉREZ, E. Produção de biocompósitos por policondensação de L-ácido láctico em hidrogéis de celulose bacteriana, Dissertação de M.Sc., UFSC, Florianópolis, SC, Brasil, 2014.

[8] RECOUVREUX, D.O.S., "Desenvolvimento de novos biomateriais baseados em celulose bacteriana para aplicações biomédicas e de engenharia de tecidos”, Tese de D.Sc., UFSC, Florianópolis, SC, Brasil, 2008.

[9] LIMA, L.R., SANTOS, D.B., SANTOS, M.V., et al., "Nanocristais de celulose a partir de celulose bacteriana”, Química Nova, v. 38, n. 9, pp. 1140-1147, 2015.

[10] TAIPINA, M.O., Nanocristais de celulose: obtenção, caracterização e modificação de superfícies, Dissertação de M.Sc., UNICAMP, Campinas, SP, Brasil, 2012. 
[11] PEZZIN, A.P.T. Obtenção e caracterização de blendas de poli(p-dionanona)/poli(L-acido lactico) (PPD/PLLA) para aplicação como prótese de menisco bioreabsorvível, Tese de D.Sc., UNICAMP, Campinas, SP, Brasil, 2001.

[12] PEREIRA, F.V., PAULA, E.L., MESQUITA, J.P., et al., "Bionanocompósitos preparados por incorporação de nanocristais de celulose em polímeros biodegradáveis por meio de evaporação de solvente, automontagem ou eletrofiação”, Química Nova, v. 37, n. 7, pp. 1209-1219, 2014.

[13] ARROYO, O.H., HUNEAULT, M.A., FAVIS, B.D., et al., "Processing and properties of PLA/thermoplastic starch/montmorillonite nanocomposites”, Polymer Composites, v. 31, n. 1, pp. 114-127, 2010.

[14] AVÉROUS, L. "Polylactic acid: synthesis, properties and applications", In: BELGACEM, M.N., GANDINI, A. (eds), Nanomers, polymers and composites from renewable resources, chapter 21, Oxford, UK, Elsevier, 2008.

[15] ALMEIDA, A.S. "Obtenção e caracterização de nanocompósitos de poli(L-lactídeo) e nanopartículas de argila sódica, argilas organofílicas e óxidos de sílica”, Dissertação de M.Sc., UFRJ, Rio de Janeiro, Rio de Janeiro, Brasil, 2010.

[16] PARIZE, D.D.S. "Estudo de filmes de poli(ácido lático) obtidos por fiação por sopro em solução reforçados com nanocristais de celulose”, Tese de D.Sc., UFSCAR, São Carlos, São Paulo, Brasil, 2016.

[17] ROSA, S.M.L. "Isolamento de nanocristais de celulose de resíduos agrícolas e emprego em nanocompósitos de polipropileno”, Tese de D.Sc., UFRS, Porto Alegre, RS, Brasil, 2012.

[18] TEIXEIRA, E.M., OLIVEIRA, C.R., MATTOSO, L.H.C., et al., "Nanofibras de algodão obtidas sob diferentes condições de hidrólise ácida”, Polímeros, v. 20, n. 4, pp. 264-268, 2010.

[19] ALEMDAR, A., SAIN, M. "Isolation and characterization of nanofibers from agricultural residues: wheat straw and soy hulls”, Bioresource Technology, v. 99, n. 6, pp. 1664-1671, 2008.

[20] MIRHOSSEINI, H., TAN, C. P., HAMID, N., et al., "Effect of arabic gum, xanthan gum and orange oil contents on zeta-potential, conductivity, stability, size index and $\mathrm{pH}$ of orange beverage emulsion”, Colloids and Surfaces: Physicochemical and Engineering Aspects, v. 315, n. 1, pp. 47-56, 2008.

[21] LIU, D., YUAN, X., BHATTACHARYYA, D., et al., "Characterisation of solution cast cellulose nanofibre - reinforced poly(lactic acid)”, Express Polymer Letters, v. 4, n. 1, pp. 26-31, 2010.

[22] JORDAN, J., JACOB, K.L., TANNENBAUM, R., et al., "Experimental trends in polymer nanocomposites—a review”, Materials Science and Engineering, v. 393, n. 1, pp. 1-11, 2005.

[23] STURCOVÁ, A., DAVIES, G.R., EICHHORN, S. J., et al., "Elastic modulus and stress-transfer properties of tunicate cellulose whiskers”, Biomacromolecules, v. 6, n. 2, pp. 1055-1061, 2005. 